\title{
Advancement and Validation of new Derivatives Spectrophotometric Method for Individual and Simultaneous Estimation of Diclofenac Sodium and Nicotinamide
}

\section{SAMAR AHMED DARWEESH ${ }^{1}$, HUSAM SALEEM KHALAF ${ }^{\star 2}$, ROKAYIA SAMIR AL-KHALISY ${ }^{3}$, HAMSA MUNEAM YASEEN ${ }^{4}$ and RUAA MUAYED MAHMOOD ${ }^{5}$}

Department of Chemistry, College of Education for Pure Science-Ibn Al-Haitham, University of Baghdad, Baghdad, Iraq.

${ }^{*}$ Corresponding author E-mail: husam250@yahoo.com

http://dx.doi.org/10.13005/ojc/340357

(Received: February 27, 2018; Accepted: April 03, 2018)

\begin{abstract}
Derivative spectrophotometry, which is primarily based on the first and second derivative spectra of absorption, was applied for individual and simultaneous spectrophotometric determination of diclofenac sodium (DS) and nicotinamide (NAM) in the ultraviolet region. The method depends on 1st and 2nd derivative UV spectrophotometry, with the amplitude of peak-to-base line, peak to peak, the area under peak at selected spectrum intervals and zero-crossing at certain wavelengths for each compound measurement. Under optimal conditions, a linear working range of 5-80 $\mu \mathrm{g} \cdot \mathrm{ml}^{-1}$ and $10-140 \mu \mathrm{g} \cdot \mathrm{ml}^{-1}$ for (DS) and (NAM) with correlation coefficient $\mathrm{R}^{2}$ between $0.9938-0.9998$. The mean \% recoveries were found to be in the range of $97.95-102.50 \%$ for two drugs. The proposed technique has been effectively applied to the estimation of (DS) and (NAM) in pharmaceutical formulations.
\end{abstract}

Keywords: UV-Visible Spectrophotometer, Derivative spectrophotometric method, Simultaneous determination, Diclofenac sodium, Nicotinamide.

\section{INTRODUCTION}

Derivative spectrophotometry is a technique of incredible usefulness for separating both qualitative and quantitative information from spectra made of uncertain bands by utilizing the first or higher derivatives of absorbance concerning wavelength ${ }^{1}$. This technique offers different advantages over the customary absorbance methods, for example: the separation of the sharp spectral features over the huge bands and the improvement of the resolution of overlapping spectra ${ }^{2}$ what's more, allow the assay of certain analyses from complex mixtures or matrices via mathematical interpretation of the absorption signal $^{3}$. UV-Vis spectroscopic approach for analysis is broadly utilized within the determination of drug in pharmaceutical preparations and for separation studies, which disposes interference from the 
formulation of matrix by utilizing zero-crossing techniques ${ }^{4}$. Many reports were found for the analysis in individual form particularly for DS and NAM including spectrophotometric method5-8, chromatographic method ${ }^{9,10}$, flow injection ${ }^{11}$, voltammetry ${ }^{12}$, potentiometric ${ }^{13}$, electrochemical method $^{14}$, capillary electrophoresis ${ }^{15,16}$.

\section{EXPERIMENTAL}

\section{Instruments}

UV-Visible double beam spectrophotometer with $10 \mathrm{~mm}$ quartz cell Shimadzu 1800, a personal computer.

\section{Chemicals and reagents}

Pharmaceutical grade DS and NAM powder received in pure form $(99.99 \%)$ was provided as an endowment from the State Company for Drug manufacture and Medical Appliances Samara-Iraq (SDI), methanol (99.7\%) provide by (SCR). All chemical substance utilized were of analytical grade.

Preparation of standard stock solution $\left(200 \mu \mathrm{g} \cdot \mathrm{mL}^{-1}\right)$, Diclofenac sodium and nicotinamide

The standard solution of (DS) and (NAM) were prepared by dissolving accurate weighted 20.0 $\mathrm{mg}$ of pure drug in $10.0 \mathrm{ml}$ of methanol and further diluted to $100 \mathrm{ml}$ with distilled water.

\section{Preparation both Diclofenac sodium and nicotinamide from dosage form}

The content of 10 Tablets and capsules was grinded and blended well. Take accurately weighted from a specific quantity of the fine powder to give an equivalent to $50 \mathrm{mg}$ for DS Tablets and $20 \mathrm{mg}$ for NAM capsules and dissolve in ten $\mathrm{mL}$ of methanol then diluted to the mark with distilled water in a volumetric flask $100 \mathrm{ml}$. The solution was filtered by utilizing filter paper (Whatman No.41) to evade any undissolved or suspended components before use; also the first part of the solution filtrate was rejected.

\section{Procedures}

Individual determination of Diclofenac sodium and nicotinamide

In $10 \mathrm{~mL}$ calibrated flask transfer aliquots of (DS) standard solutions containing 50-800 $\mu \mathrm{g}$ (or NAM standard solutions containing 100-1400 $\mu \mathrm{g}$ ), and dilute with $10 \%$ methanol solution to the mark. The spectrum for each solution was recorded against a $10 \%$ methanol solution as blank. Zero order spectrums were then manipulated for each to get its first derivative (D1) and second derivative (D2).

\section{Simultaneous determination of Diclofenac sodium and nicotinamide}

(I) The content of a series of $10 \mathrm{~mL}$ calibrated flasks containing different amounts $(50-800) \mu \mathrm{g}$ of DS standard solutions and $50 \mu \mathrm{g}$ of (NAM) solution the mixture was then diluted with $10 \%$ methanol solution to the mark. Record the spectrum for each solution against a $10 \%$ methanol solution as a blank. The recorded spectra were then manipulated to get D1 and D2.

(II) The content of a series of $10 \mathrm{~mL}$ calibrated flasks containing different amounts (100-1400) $\mu \mathrm{g}$ of NAM standard solutions and $100 \mu \mathrm{g}$ of DS solutionthe mixture was then diluted with $10 \%$ methanol solution to the mark. The spectrum for each solution was recorded against a $10 \%$ methanol solution as a blank. The recorded spectra were then manipulated to get D1 and D2.

\section{RESULT AND DISCUSSION}

\section{Absorption spectra}

The absorption spectra were recordof each compounds DS, NAM then their mixtureagainst $10 \%$ methanol solution as a blank. Fig. 1 (a) demonstrates the absorption spectrum of DS 10 $\mu \mathrm{g} . \mathrm{mL}^{-1}$ with maximum wavelength at $276 \mathrm{~nm}$, (b) demonstrates the absorption spectrum of (NAM) $50 \mu \mathrm{g} \cdot \mathrm{mL}^{-1}$ with two maxima wavelength of absorption at $214 \mathrm{~nm}$ and $262 \mathrm{~nm}$. The aggregate spectrum to the mixture is demonstrating in (c) with two $\lambda$ max 212 and $266 \mathrm{~nm}$.

\section{First derivative mode and 2nd derivative mode}

The derivative spectra 1st, 2nd order of DS and NAM and for their blend are appeared within Fig. 2, Fig. 3 respectively. Clearly there is a large overlap in spectra of diclofenac sodium and nicotinamide hence, their determination, making use of the zero order absorption measurements, at the point when present in the same solution it is very difficult when utilizing customary two wavelengths of $\lambda \max$ or the tangential base-line approach strategies ${ }^{17}$. Then again, derivative technique is of a specific utility in finding the concentration of single component in a blends, with a large overlapping in spectrum. Consequently, both first, second order derivative spectrophotometric methods have been applied. 


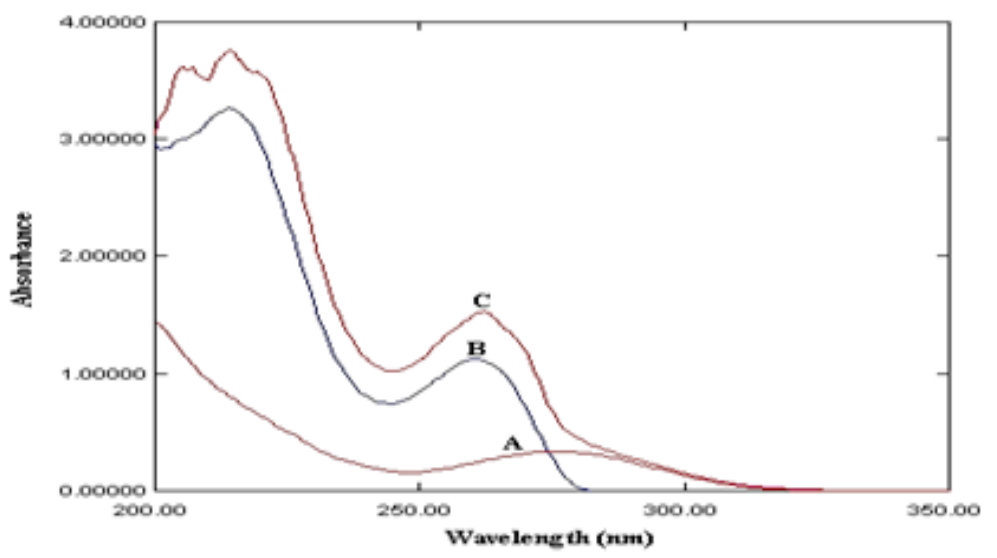

Fig. 1. Absorption spectra of: (A) $10 \mu \mathrm{g} \cdot \mathrm{mL}^{-1}(\mathrm{DS}),(B) 50 \mu \mathrm{g} \cdot \mathrm{mL}^{-1}(\mathrm{NAM})$ and(C) a mixture of $10 \mu \mathrm{g} . \mathrm{mL}^{-1}$ Diclofenac sodium and50 $\mu \mathrm{g} \cdot \mathrm{mL}^{-1}$ nicotinamide

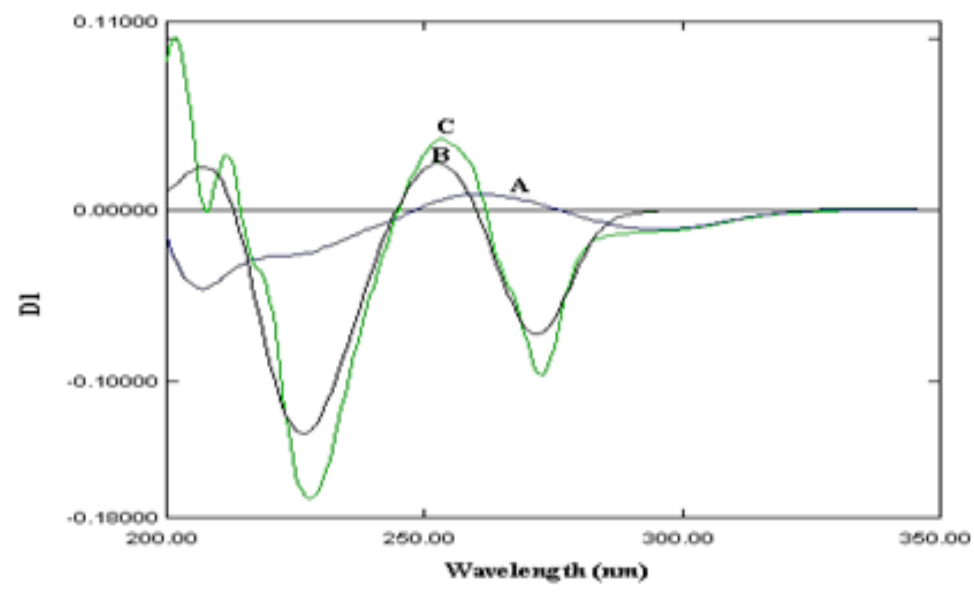

Fig. 2. 1st derivative spectra of (A) $10 \mu \mathrm{g} . \mathrm{mL}^{-1}$ Diclofenac sodium, (B) $50 \mu \mathrm{g} . \mathrm{mL}^{-1}$ nicotinamide and (C) a mixture of $10 \mu \mathrm{g} \cdot \mathrm{mL}^{-1}$ diclofenac sodium and $50 \mu \mathrm{g} \cdot \mathrm{mL}^{-1}$ nicotinamide

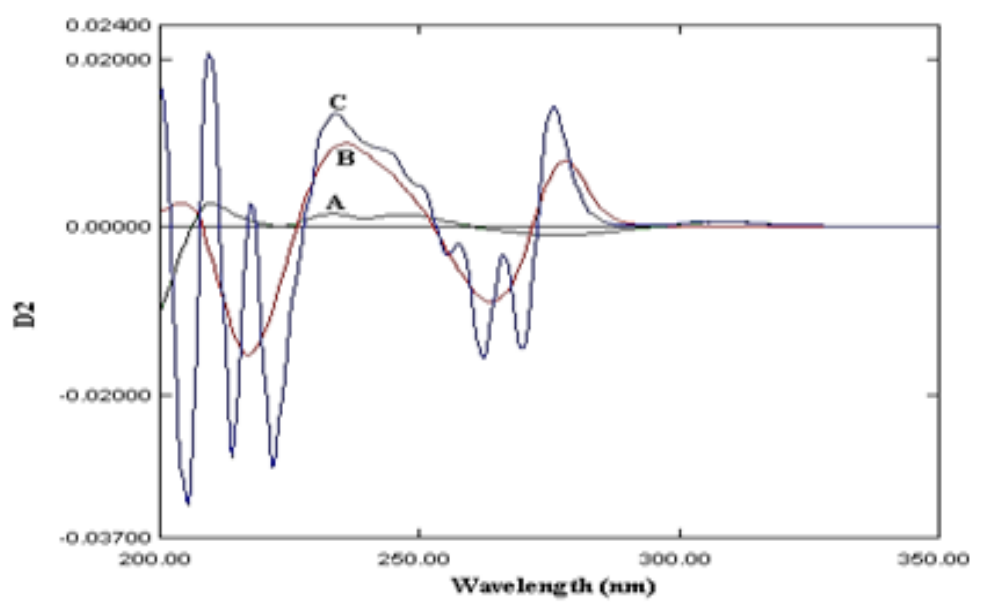

Fig. 3. 2nd derivative spectra of (A) $10 \mu \mathrm{g} . \mathrm{mL}^{-1}$ diclofenac sodium, (B) $50 \mu \mathrm{g} . \mathrm{mL}^{-1}$ nicotinamide and (C) a mixture of $10 \mu \mathrm{g} \cdot \mathrm{mL}^{-1}$ diclofenac sodium and $50 \mu \mathrm{g} \cdot \mathrm{mL}^{-1}$ nicotinamide 
In the existing work, graphically peak-to-baseline, peak to peak, zero-crossing technique in addition to peak area were utilized to deal with derivatives spectra to complete the data. Truth be told, Theany one of these techniques in the 1st and 2nd derivative modes indicate good proportion to diclofenac sodium and nicotinamide amounts in their blends.

Figure 4 and Fig. 5 illustrate sets of 1 st order spectra of medley containing (5-80) $\mathrm{gg}_{\mathrm{gl}}{ }^{-1}$ of diclofenac sodium in the existence of $\left(5 \mu \mathrm{g} \cdot \mathrm{ml}^{-1}\right)$ nicotinamide and (10-140) $\mu \mathrm{g} \cdot \mathrm{ml}^{-1}$ of nicotinamide in the existence of $\left(10 \mu \mathrm{g} \cdot \mathrm{ml}^{-1}\right)$ diclofenac sodium respectively. Fig. 4 indicate that when the amount of nicotinamide is kept constant and varied the concentration of diclofenac sodium, the peak-to-base line, peak to peak, peak areas and zero crossing of nicotinamide were proportional to the concentration of diclofenac sodium. Moreover, the same features were found for the determination of nicotinamidein Fig. 5, i.e. area under peak, peak-to-baseline, peak to peak and zero crossing of diclofenac sodium were in proportion to the concentration of nicotinamide (Table 1 and 2).

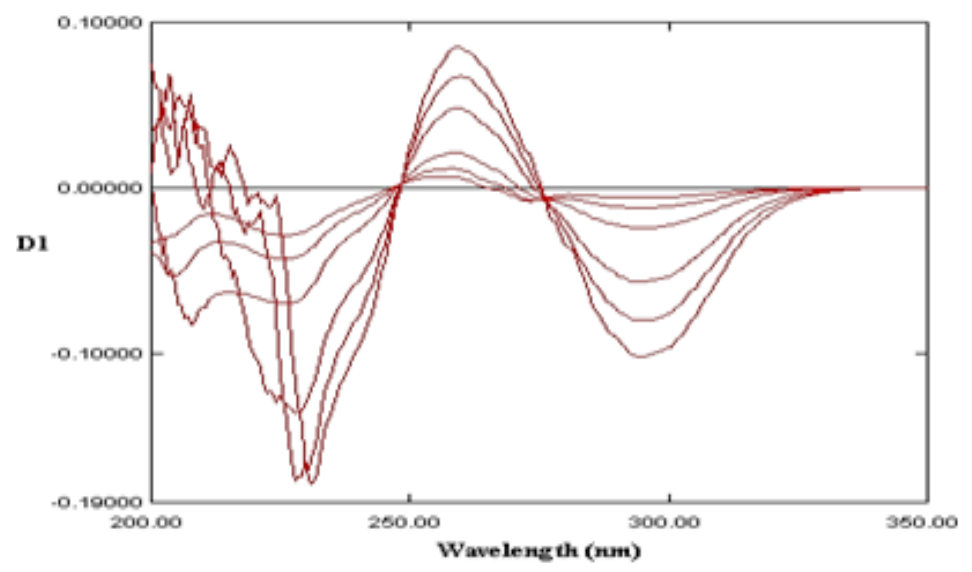

Fig. 4. First derivative spectra of mixture contain $\left(5,10,20,40,60\right.$ and $\left.80 \mu g . \mathrm{mL}^{-1}\right)$; diclofenac sodium with $\left(5 \mu \mathrm{g} . \mathrm{mL}^{-1}\right)$ nicotinamide

Table 1: Statistical analysis for the determination of diclofenac sodium

\begin{tabular}{|c|c|c|c|c|c|c|}
\hline Drug & $\begin{array}{l}\text { Order of } \\
\text { derivative }\end{array}$ & $\begin{array}{c}\text { Mode of } \\
\text { calculations }\end{array}$ & $\lambda(\mathrm{nm})$ & Regression equation & $\mathrm{R}^{2}$ & Slope \\
\hline \multirow{15}{*}{ 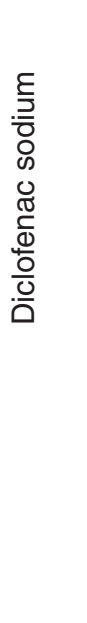 } & \multirow[t]{7}{*}{ First } & Peak to baseline & 259 & $y=0.0011 x+0.0014$ & 0.9955 & 0.0011 \\
\hline & & Peak to baseline & 295 & $y=-0.0013 x+0.0002$ & 0.9955 & -0.0013 \\
\hline & & Peak to peak & $259-295$ & $y=0.0024 x+0.0012$ & 0.9955 & 0.0024 \\
\hline & & Area under peak & $248.5-276$ & $y=0.0188 x-0.0095$ & 0.9961 & 0.0188 \\
\hline & & Area under peak & $276-334$ & $y=-0.0367 x+0.1702$ & 0.9944 & -0.0367 \\
\hline & & Zero cross & 260 & $y=0.0011 x+0.0008$ & 0.9948 & 0.0011 \\
\hline & & Zero cross & 296 & $y=-0.0013 x+0.0001$ & 0.9955 & -0.0013 \\
\hline & \multirow[t]{8}{*}{ Second } & Peak to baseline & 247 & $y=0.0002 x+0.0004$ & 0.9965 & 0.0002 \\
\hline & & Peak to baseline & 310 & $y=7 E-05 x-3 E-05$ & 0.9961 & 7E-05 \\
\hline & & Area under peak & $239-260$ & $y=0.0017 x+0.0011$ & 0.9988 & 0.0017 \\
\hline & & Area under peak & $260-294$ & $y=-0.0027 x+0.0154$ & 0.9961 & -0.0027 \\
\hline & & Area under peak & $294-340$ & $y=0.0013 x-0.0005$ & 0.9988 & 0.0013 \\
\hline & & Zero cross & 252 & $y=0.0001 x+0.0002$ & 0.9955 & 0.0001 \\
\hline & & Zero cross & 272 & $y=-0.0001 x-0.0002$ & 0.9938 & -0.0001 \\
\hline & & Zero cross & 310 & $y=7 E-05 x-3 E-05$ & 0.9961 & 7E-05 \\
\hline
\end{tabular}


Table 2: Statistical analyses for the determination of nicotinamide

\begin{tabular}{|c|c|c|c|c|c|c|}
\hline Drug & $\begin{array}{l}\text { Order of } \\
\text { derivative }\end{array}$ & $\begin{array}{c}\text { Mode of } \\
\text { calculations }\end{array}$ & $\lambda(\mathrm{nm})$ & Regression equation & $\mathrm{R}^{2}$ & Slope \\
\hline \multirow{13}{*}{ 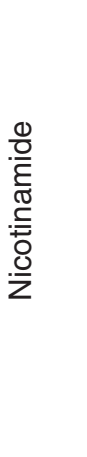 } & \multirow[t]{7}{*}{ First } & Peak to baseline & 253 & $y=0.0007 x+0.0057$ & 0.9994 & 0.0007 \\
\hline & & Peak to baseline & 272 & $y=-0.0021 x+0.0068$ & 0.9998 & -0.0021 \\
\hline & & Peak to peak & $253-272$ & $y=0.0028 x-0.0011$ & 0.9998 & 0.0028 \\
\hline & & Area under peak & $244.5-261$ & $y=0.0074 x+0.0393$ & 0.9995 & 0.0074 \\
\hline & & Area under peak & $261-334$ & $y=-0.0256 x-0.5788$ & 0.999 & -0.0256 \\
\hline & & Zero cross & 248 & $y=0.0005 x-0.0009$ & 0.9998 & 0.0005 \\
\hline & & Zero cross & 276 & $y=-0.0014 x+0.0017$ & 0.9997 & -0.0014 \\
\hline & \multirow[t]{6}{*}{ Second } & Peak to baseline & 244 & $y=0.0002 x+0.0013$ & 0.9995 & 0.0002 \\
\hline & & Peak to baseline & 262 & $y=-0.0004 x+6 E-05$ & 0.9998 & -0.0004 \\
\hline & & Peak to baseline & 270 & $y=-0.0003 x-0.0006$ & 0.9995 & -0.0003 \\
\hline & & Peak to baseline & 275 & $y=0.0003 x-0.0013$ & 0.9996 & 0.0003 \\
\hline & & Peak to peak & $270-275$ & $y=0.0006 x-0.0003$ & 0.9992 & 0.0006 \\
\hline & & Area under peak & $272-329$ & $y=0.0039 x+0.0235$ & 0.9995 & 0.0039 \\
\hline
\end{tabular}

Table 3: Accuracy and precision of the methods

\begin{tabular}{lcccccc}
\hline Drug & Approach of analysis & $\begin{array}{c}\text { Wavelengths } \\
\lambda(\mathrm{nm})\end{array}$ & $\begin{array}{c}\text { Taken } \\
\left(\mu \mathrm{g} \cdot \mathrm{ml}^{-1}\right)\end{array}$ & $\begin{array}{c}\text { Found } \\
\left(\mu \mathrm{g} \cdot \mathrm{ml}^{-1}\right)\end{array}$ & RE\% & ${ }^{*} \mathrm{RSD} \%$ \\
\hline $\begin{array}{l}\text { Diclofenac } \\
\left(\mu \mathrm{g} \cdot \mathrm{ml}^{-1}\right)\end{array}$ & $\begin{array}{c}\text { First order } \\
\text { (area under peak) }\end{array}$ & $248.5-276$ & 30.00 & 30.34 & 1.133 & 2.130 \\
& $\quad$ Second order & & 60.00 & 59.57 & -0.717 & 0.499 \\
& $\begin{array}{c}\text { (area under peak) } \\
\text { nicotinamide }\end{array}$ & $239-260$ & 30.00 & 29.62 & -1.267 & 0.668 \\
& $\quad$ First order & & 60.00 & 60.55 & 0.917 & 0.365 \\
& $\quad$ (zero cross) & 248 & 50.00 & 49.70 & -0.600 & 0.748 \\
& $\begin{array}{c}\text { Second order } \\
\text { (peak to base line) }\end{array}$ & 262 & 100.00 & 99.45 & -0.550 & 0.235 \\
& & & 50.00 & 50.38 & 0.760 & 0.878 \\
& & & 100.00 & 99.67 & -0.330 & 0.277 \\
\hline
\end{tabular}

Table 4: Results for analysis of diclofenac sodium and nicotinamide in four pharmaceutical formulation samples

\begin{tabular}{|c|c|c|c|c|c|c|}
\hline \multirow{2}{*}{$\begin{array}{l}\text { Pharmaceutical } \\
\text { preparation }\end{array}$} & \multirow{2}{*}{$\begin{array}{c}\text { Method of } \\
\text { analysis }\end{array}$} & \multirow[t]{2}{*}{$\lambda(\mathrm{nm})$} & \multicolumn{2}{|c|}{ amount (mg) } & \multirow[t]{2}{*}{ Rec.\% } & \multirow[t]{2}{*}{${ }^{*} \mathrm{RSD} \%$} \\
\hline & & & Taken & Found* & & \\
\hline $\begin{array}{l}\text { Olfen-50 } \\
\text { Acion }\end{array}$ & $\begin{array}{c}\text { First order } \\
\text { (area under peak) }\end{array}$ & $248.5-276.0$ & 50 & 50.41 & 100.82 & 0.778 \\
\hline switzerland & $\begin{array}{l}\text { Second order } \\
\text { (area under peak) }\end{array}$ & $239.0-260.0$ & 50 & 49.68 & 99.36 & 0.702 \\
\hline $\begin{array}{l}\text { Optifenac-50 } \\
\text { M. H. drugs }\end{array}$ & $\begin{array}{c}\text { First order } \\
\text { (area under peak) }\end{array}$ & $248.5-276.0$ & 50 & 49.54 & 99.08 & 0.667 \\
\hline India & $\begin{array}{l}\text { First order } \\
\text { (area under peak) }\end{array}$ & $239.0-260.0$ & 50 & 49.25 & 98.5 & 0.806 \\
\hline $\begin{array}{l}\text { Modoplex Caps } \\
\text { M. V. C. }\end{array}$ & $\begin{array}{l}\text { First order } \\
\text { (zero cross) }\end{array}$ & 248 & 20 & 19.7 & 98.5 & 2.005 \\
\hline India & $\begin{array}{c}\text { Second order } \\
\text { (peak to base line) }\end{array}$ & 262 & 20 & 20.28 & 101.4 & 1.482 \\
\hline $\begin{array}{l}\text { P-blex Caps } \\
\text { S. D. I. }\end{array}$ & $\begin{array}{l}\text { First order } \\
\text { (zero cross) }\end{array}$ & 248 & 20 & 20.5 & 102.5 & 0.959 \\
\hline Iraq & $\begin{array}{c}\text { Second order } \\
\text { (peak to base line) }\end{array}$ & 262 & 20 & 19.59 & 97.95 & 1.244 \\
\hline
\end{tabular}

${ }^{\star}$ Average of three determinations. 


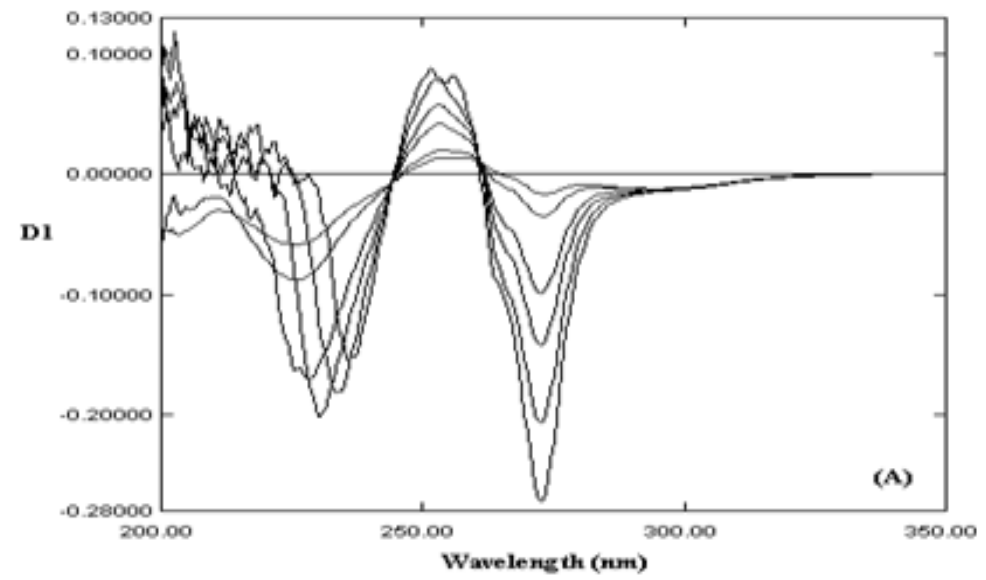

Fig. 5. First derivative spectra of mixture contain $\left(10,20,50,70,100\right.$ and $\left.140 \mu \mathrm{g}^{-1}\right)$; nicotinamide with $\left(10 \mu \mathrm{g} . \mathrm{mL}^{-1}\right)$ diclofenac sodium

In the further sets of 2 nd derivative of the same above blend, as illustrated in Fig. 6 and Fig. 7. By applying the same mentioned approached in account peak amplitudes (in millimeter) at peak-to-baseline, peak to peak and at zero crossing point of the other compound, and peak areas at selected wavelengths intervals enable the measurement of diclofenac sodium and nicotinamide respectively (Table 1 and 2 ).

\section{Calibration graph and statistical analysis}

The analytical characteristics and most statistical data for each of the proposed methods are given in (Table 1 and 2). Under optimum conditions, linear calibration curve was obtained in the range of $\left(5-80 \mu \mathrm{g} \cdot \mathrm{ml}^{-1}\right)$ for DS and (10-140 $\left.\mu \mathrm{g} \cdot \mathrm{ml}^{-1}\right)$ for NAM with correlation coefficient values ranging between (0.9938-0.9998)

\section{Accuracy and precision}

Under the optimum conditions, the accuracy and precision of the proposed method (peak to baseline, zero cross and area under the peak for each of first and second order derivative modes) were checked. Table 3 shows the values of relative error percent and relative standard deviation percent for two different level of concentration of diclofenac sodium and nicotinamide with three replicate.

\section{Application in dosage form}

The proposed method first and second procedures were successfully applied for direct determination of diclofenac sodium in tablets and nicotinamide in capsules. The results obtained are presented in Table 4, and are in quite agreement with the spiked values. Good recovery $97.95-102.50 \%$ and

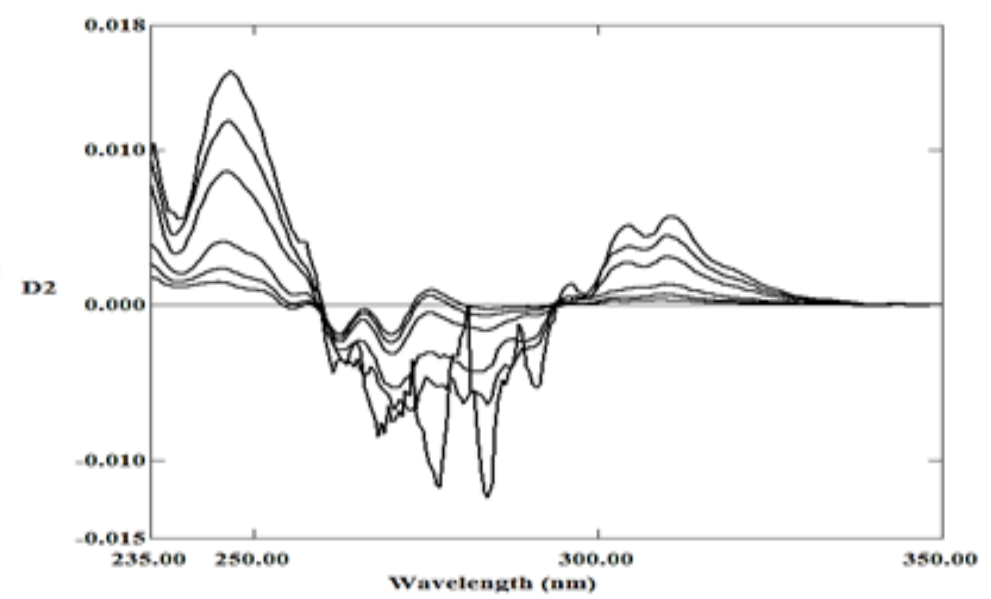

Fig. 6. Second derivative spectra of mixture contain $\left(5,10,20,40,60\right.$ and $\left.80 \mu g . \mathrm{mL}^{-1}\right)$; diclofenac sodium in existence of $\left(5 \mu \mathrm{g} . \mathrm{mL}^{-1}\right)$ nicotinamide 


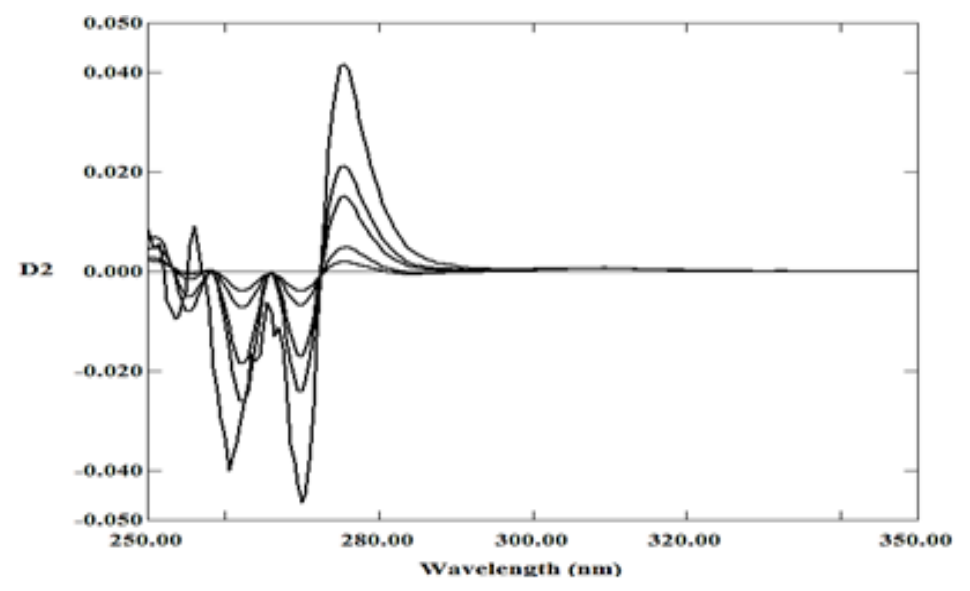

Fig. 7. Second derivative spectra of mixture contain $\left(10,20,50,70,100\right.$ and $\left.140 \mu \mathrm{g} . \mathrm{mL}^{-1}\right)$; nicotinamide in existence of $\left(10 \mu \mathrm{g} . \mathrm{mL}^{-1}\right)$ diclofenac sodium

RSD\% values $0.667-2.005 \%$ indicated the suitability of these methods for routine analysis of diclofenac sodium and nicotinamide.

\section{CONCLUSION}

Derivative Spectrophotometric technique was found to be sensitive, simple, rapid, economical, the results indicates that a good accuracy and precision of the proposed method, good recovery from the results applications in dosage form and it can be used in routine analysis of diclofenac sodium and nicotinamide in their pure forms, dosage form without prior separation or treatment.

In this work, 1st and 2nd derivative modes indicate good proportion to diclofenac sodium and nicotinamide amounts in pure form and in their blends, by graphically peak-to-baseline, peak to peak, zero-crossing technique in addition to peak area were utilized to deal with derivatives spectra to complete the data.

\section{REFERENCE}

1. Ojeda C. B. and Rojas F. S. "Recent developments in derivative ultraviolet /visible absorption spectrophotometry" Analytica Chimica Acta., 2004, 518, 1-24.

2. Stanisz.B, Paszun S and LesniakM, "Validation of UV Derivative Spectrophotometric Method for Determination of Benazepril Hydrochloride in Tablets and Evaluation of Its Stability" Acta Poloniae Pharmaceutica-Drug Research., 2009, 66(4), 343-349.

3. LakissH, Ilie M, Baconi D. L. and Balalau D. "Derivative UV Spectrophotometry Used for The Assay of Diazepam from Human Blood Plasma" Farmacia., 2012, 60(4), 565-570.

4. Attimarad M, Al-Dhubiab B. E, Alhaider I. A., Nair A B, Harsha N. S. and Ahmed K. M. "Simultaneous determination of moxifloxacin and cefixime by first and ratio first derivative ultraviolet spectrophotometry" Attimarad Chemistry Central Journal., 2012, 6(105), 1-7.

5. raju T. G., Vinukonda A, Akki R., Gayatriramya M, Gupta S. K. and Naik V. V. "Simultaneous Estimation of Diclofenac Sodium and Rabeprazole in Combined Dosage Form" IJRPC., 2012, 2(3), 873-875.

6. Sharma M. C. and Sharma S., "Determination and Validation of UV Spectrophotometric method for Estimation of Paracetamol and Diclofenac Sodium in Tablet Dosage Forms Using Hydrotropic Solubilizing Agents" Int. J. PharmTech Res., 2011, 3(1), 244-247.

7. López-de-Alba P.L., López-Martínez L, Cerdáb V. and Amador-Hernández J. "Simultaneous Determination and Classification of Riboflavin, Thiamine, Nicotinamide and Pyridoxine in Pharmaceutical Formulations, by UV-Visible Spectrophotometry and Multivariate Analysis" J. Braz. Chem. Soc., 2006, 17(4), 715-722. 
8. Mantovania V. E., Goicoecheab H. C. and Collado A. C. "Simultaneus Determination of Nicotinamide and Inosine in Ophtalmic Solutions by UV Spectrophotometry and PLS-1 Multivariate Calibration" Analytical Letters., 2001, 34, 363-376.

9. Hamad Z.S. and Yahya B.M. "High performance liquid chromatographic determination of diclofenac sodium in plasma of the rat" Iraqi Journal of Veterinary Sciences., 2013, 27(2), 103-107.

10. Yagar E. F., Eggers R. and Lang T. H. R. "Quantitative Investigation of Trigonelline, Nicotinic Acid, and Nicotinamide in Foods, Urine, and Plasma by Means of LC-MS/MS and Stable Isotope Dilution Analysis" J. Agric. Food Chem., 2008, 56(23), 11114-11121.

11. Gimenes D. T., de Freitas J. M., Munoz R. A. A. and E. M. Richter "Flow-Injection Amperometric Method for Determination of Diclofenac in Pharmaceutical Formulations Using a Boron-Doped Diamond Electrode" Electroanalysis., 2011, 23(11), 2521-2525.

12. Afkhami A., Bahiraei A., T. Madrakian "Gold nanoparticle/multi-walled carbon nanotube modified glassy carbon electrode as a sensitive voltammetric sensor for the determination of diclofenac sodium"Materials Science and Engineering: C., 2016, 59, 168-176.

13. Sharnin V. A., Dushina S. V., Zevakin M. A.,
Gushchina A.S., Grazhdan K.V."Potentiometric and calorimetric study on stability of nicotinamide complexes of silver(I) and copper(II) in aqueous ethanol and dimethylsulfoxide" Inorganica Chimica Acta., 2009, 362, 437-442.

14. Karimi-Maleh H., Tahernejad-Javazmi F., Daryanavard M., Hadadzadeh H., Ensafi A. A. and Abbasghorbani M. "Electrocatalytic and Simultaneous Determination of Ascorbic Acid, Nicotinamide Adenine Dinucleotide and Folic Acid at Ruthenium(II) Complex-ZnO/ CNTs Nanocomposite Modified Carbon Paste Electrode" Electroanalysis, 2014, 26, 962-970.

15. Cunha R. R., Gimenes D. T., Munoz R. A. A., C. L. do Lago and E. M. Richter "Simultaneous determination of diclofenac and its common counter-ions in less than 1 minute using capillary electrophoresis with contactless conductivity detection" Electrophoresis, 2013, 34, 1423-1428.

16. Wise D. D. and Shear J. B. "Quantitation of nicotinamide and serotonin derivatives and detection of Flavin's in neuronal extracts using capillary electrophoresis with multiphoton-excited fluorescence" Journal of Chromatography A., 2006, 11111, 153-158.

17. Haver T. C. O' and Green G. L. "The Small Modulation Case: Derivative Spectroscopy" Anal. Chem., 1976, 48, 312. 